\title{
NOS3 27-bp and IL4 70-bp VNTR Polymorphisms Do Not Contribute to the Risk of Sickle Cell Crisis
}

\author{
NOS3 27-bp ve IL4 70-bp VNTR Polimorfizmleri Orak Hücreli Anemide Kriz Riskine
}

Katkıda Bulunmaz

\author{
Henu Verma1, Hrishikesh Mishra1, P. K. Khodiar², P. K. Patra1,2, L. V. K. S. Bhaskar1 \\ 1Sickle Cell Institute Chhattisgarh, Division of Research, Raipur, India \\ 2Pt. JNM Medical College, Department of Biochemistry, Raipur, India
}

To the Editor,

A great deal of data support the direct involvement of the vascular endothelium, complex cellular interactions, and global inflammation-mediated cell activation in triggering vasoocclusive crisis (VOC) in sickle cell disease (SCD) [1]. In the transgenic mice model for $\mathrm{SCD}$, it has been shown that nitric oxide (NO) protects the mice from VOC [2]. Elevated plasma levels of certain proinflammatory cytokines support a role for cytokine-driven inflammation in SCD. The aim of the present study was to evaluate the role of the NOS3 27-bp variable number tandem repeat (VNTR) and IL4 intron-3 VNTR functional polymorphisms in the development of crisis in Indian SCD patients. The study protocol was approved by the Institutional Ethics Committee of the Sickle Cell Institute Chhattisgarh, Raipur, India. Written informed consent was obtained from the study participants. A total of 256 individuals with SCD (55.5\% men) were divided into two groups based on the history of VOC. The patients hospitalized with recurrent VOC were considered as the frequent crisis (FC) group $(n=140 ; 54.7 \%)$ and patients who had not experienced any VOC during the past 1 year were considered as the infrequent crisis (IFC) group ( $n=116 ; 45.3 \%$ ). Genotyping of the NOS3 27-bp VNTR [3] and IL4 intron-3 VNTR [4] functional polymorphisms was performed and results were compared between the FC and IFC groups.

The genotype frequencies were in agreement with HardyWeinberg equilibrium for both the NOS3 27-bp $(p=0.063)$ and the IL4 70-bp ( $p=0.614)$ VNTR. The genotype frequencies were not significantly different between the FC and IFC groups (Table 1). Similarly, the risk of frequent crisis was not found to be different between male and female SCD patients or between SCD patients with different HbF levels or different age groups (Table 1). Several lines of evidence suggest that there is vascular dysfunction and impaired NO bioactivity in SCD. Although no significant differences were observed in plasma NO metabolites between controls and SCD patients in the steady state, a significant reduction was noticed during VOC or acute chest syndrome [5]. Analysis of three NOS3 gene polymorphisms did not reveal a significant association with severe clinical manifestations in Brazilian SCD patients [6]. In contrast to this, in another study a significant association of NOS3 variants with VOC in SCD patients was reported [7]. However, our results indicate that the NOS3 27-bp VNTR polymorphism is not associated with the risk of frequent crises. Although the role of IL4 in SCD is controversial, increased serum IL4 levels were found in steady-state SCD patients compared to normal healthy controls [8]. Remarkably elevated levels of IL4 were noted in a VOC group compared to steady-state SCD patients and healthy controls [9]. IL4 levels correlated well with SCD status in Jamaicans, while exhibiting an ethnic difference between British and Jamaican children [10]. So far there are no published studies concerning IL4 SNPs and SCD or its complications. As these results conflict with the biological plausibility that NO and interleukin levels modulate SCD, they deserve careful interpretation and further exploration.

Keywords: Sickle cell disease, Crisis, NOS3, IL4

Anahtar Sözcükler: Orak hücre hastalığı, Kriz, NOS3, IL4

\section{Ethics}

Ethics Committee Approval: The study protocol was approved by the Institutional Ethics Committee of the Sickle Cell Institute Chhattisgarh, Raipur, India, Informed Consent: Written informed consent was obtained from the study participants.

\section{Authorship Contributions}

Concept: L. V. K. S. Bhaskar, P. K. Patra; Design: L. V. K. S. Bhaskar, P. K. Patra; Data Collection or Processing: Henu Verma, L. V. K. S. Bhaskar; Analysis or Interpretation: L. V. K. S. Bhaskar; Literature Search: P. K. Khodiar, Henu Verma, Hrishikesh Mishra; Writing: Henu Verma, L. V. K. S. Bhaskar.

Conflict of Interest: No conflict of interest was declared by the authors. 


\begin{tabular}{|c|c|c|c|c|c|c|}
\hline \multirow[b]{2}{*}{ Genotype } & \multicolumn{2}{|c|}{ Vaso-Occlusive Crisis } & \multicolumn{2}{|c|}{ Unadjusted } & \multicolumn{2}{|c|}{ Adjusted for Age and Sex } \\
\hline & FC & IFC & OR (95\% Cl) & p-value & OR $(95 \% \mathrm{CI})$ & p-value \\
\hline \multicolumn{7}{|c|}{ NOS3 27-bp VNTR } \\
\hline $4 \mathrm{bb}$ & $101(72.1)$ & 89 (76.7) & \multicolumn{4}{|l|}{ Reference } \\
\hline $4 a b$ & 39 (27.9) & $26(22.4)$ & $1.32(0.75-2.34)$ & 0.339 & $1.32(0.75-2.35)$ & 0.338 \\
\hline $4 a a$ & $0(0)$ & $1(0.9)$ & - & - & - & - \\
\hline \multicolumn{7}{|c|}{ IL4 70-bp VNTR } \\
\hline $3 R 3 R$ & $83(59.3)$ & $67(57.8)$ & \multicolumn{4}{|l|}{ Reference } \\
\hline 2R3R & $51(36.4)$ & $39(33.6)$ & $1.06(0.62-1.79)$ & 0.840 & $1.04(0.61-1.76)$ & 0.897 \\
\hline $2 \mathrm{R} 2 \mathrm{R}$ & $6(4.3)$ & $10(8.6)$ & $0.48(0.17-1.40)$ & 0.181 & $0.49(0.17-1.41)$ & 0.184 \\
\hline \multicolumn{7}{|l|}{ Sex } \\
\hline Male & $78(55.7)$ & $64(55.2)$ & \multicolumn{4}{|l|}{ Reference } \\
\hline Female & $62(44.3)$ & 52 (44.8) & $0.98(0.60-1.61)$ & 0.931 & $0.97(0.59-1.59)$ & 0.896 \\
\hline \multicolumn{7}{|l|}{$\mathrm{HbF}$} \\
\hline$>20.1 \%$ & $66(47.1)$ & $60(51.7)$ & \multicolumn{4}{|l|}{ Reference } \\
\hline $10.1 \%-20 \%$ & $59(42.1)$ & $43(37.1)$ & $1.25(0.74-2.11)$ & 0.140 & $1.27(0.75-2.16)$ & 0.374 \\
\hline$<10 \%$ & $15(10.7)$ & $13(11.2)$ & $0.105(0.46-2.38)$ & 0.909 & $1.05(0.46-2.40)$ & 0.916 \\
\hline \multicolumn{7}{|l|}{ Age } \\
\hline$<10$ years & $32(22.9)$ & $20(17.2)$ & \multicolumn{4}{|l|}{ Reference } \\
\hline $10.1-20$ years & $65(46.41)$ & $76(65.5)$ & 0.54 (0.28-1.02) & 0.059 & $0.53(0.27-1.02)$ & 0.056 \\
\hline$>20.1$ years & 43 (30.7) & $20(17.2)$ & $1.34(0.62-2.90)$ & 0.452 & 1.33 (0.61-2.88) & 0.457 \\
\hline
\end{tabular}

Financial Disclosure: The authors acknowledge funding from the Sickle Cell Institute Chhattisgarh, Government of Chhattisgarh, and CCOST, Government of Chhattisgarh (Project Ref. No. 2740/ CCOST/MRP/2015).

\section{References}

1. Bunn HF. Pathogenesis and treatment of sickle cell disease. N Engl J Med 1997;337:762-769.

2. Wu D, He L, Chen L. Apelin/APJ system: a promising therapy target for hypertension. Mol Biol Rep 2014;41:6691-6703.

3. Yoon $\mathrm{Y}$, Song J, Hong SH, Kim JQ. Plasma nitric oxide concentrations and nitric oxide synthase gene polymorphisms in coronary artery disease. Clin Chem 2000;46:1626-1630.

4. Jha AN, Singh VK, Kumari N, Singh A, Antony J, van Tong $H$, Singh S, Pati SS, Patra PK, Singh R, Toan NL, Song LH, Assaf A, Messias-Reason IJ, Velavan TP, Singh L, Thangaraj K. IL-4 haplotype -590T, -34T and intron-3 VNTR R2 is associated with reduced malaria risk among ancestral Indian tribal populations. PLoS One 2012;7:e48136.
5. Stuart MJ, Setty BN. Sickle cell acute chest syndrome: pathogenesis and rationale for treatment. Blood 1999;94:1555-1560.

6. Vargas $A E$, da Silva MA, Silla $L$, Chies JA. Polymorphisms of chemokine receptors and eNOS in Brazilian patients with sickle cell disease. Tissue Antigens 2005;66:683-690.

7. Tantawy AA, Adly AA, Ismail EA, Aly SH. Endothelial nitric oxide synthase gene intron 4 VNTR polymorphism in sickle cell disease: relation to vasculopathy and disease severity. Pediatr Blood Cancer 2015;62:389-394.

8. Raghupathy R, Haider MZ, Azizieh F, Abdelsalam R, D'Souza TM, Adekile AD. Th1 and Th2 cytokine profiles in sickle cell disease. Acta Haematol 2000;103:197-202.

9. Musa BO, Onyemelukwe GC, Hambolu JO, Mamman Al, Isa AH. Pattern of serum cytokine expression and T-cell subsets in sickle cell disease patients in vaso-occlusive crisis. Clin Vaccine Immunol 2010;17:602-608.

10. Knight-Madden J, Vergani D, Patey R, Sylvester K, Hussain MJ, Forrester T, Greenough A. Cytokine levels and profiles in children related to sickle cell disease and asthma status. J Interferon Cytokine Res 2012;32:1-5. 